\title{
LH-RH Neuron System of the Newt by Immunohistochemical Study*
}

\author{
Seiichi Kubo, Kenji Watanabe, Yasuhiko Ibata and Yutaka Sano \\ Department of Anatomy (Profs. Y. SAno and Y. IBATA), \\ Kyoto Prefectural University of Medicine, Kyoto, Japan
}

Received March 30, 1979

\begin{abstract}
Summary. The location of LH-RH producing neurons, the pathways and terminal distribution of their fibers in the newt, Cynops pyrrhogaster were studied immunohistochemically. The LH-RH positive perikarya are located in the nucleus of the diagonal band of Broca and the medial septal nucleus. No LH-RH immunoreactive neuronal perikarya could be detected in the diencephalon. The pathways of fibers originating from the LHRH reactive neurons were classified into three groups: the first project to the median eminence, the second to the olfactory bulb and the third to the habenular nucleus. The latter two pathways are extrahypothalamic, similar to those in mammals. These observations are briefly discussed and compared with those in other amphibian and mammalian species.
\end{abstract}

The availability of synthetic luteinizing hormone-releasing hormone (LH-RH) and progress in immunohistochemical techniques have led to verification of LH-RH neurons and their terminals within the central nervous system of several mammalian species (e.g. Barry et al., 1973; King et al., 1974; Barry and Carette, 1975; Sétáló et al., 1976; Silverman, 1976; Ibata and Watanabe, 1977; Ibata et al., 1978). In vertebrates, immunofluorescence neuron fibers and terminals with positive immunoreactivity to antisera to synthetic $\mathrm{LH}-\mathrm{RH}$ have also been observed in the telencephalon and diencephalon, including the median eminence of birds and frogs (SHARP et al., 1975; McNeill et al., 1976; Doerr-Schott and Dubois, 1976; Goos et al., 1976; Alpert et al., 1976). However, there has been no report of the LH-RH neuron system in the brain of the newt (Urodela) whose brain is more primitive than that of the frog (Anura). The aim of the present study is to clarify the distribution of LH-RH in the brain of the newt by immunohistochemical procedures and amphibian and mammalian features are then compared.

\footnotetext{
* This work is dedicated to the memory of the late Prof. Dr. W. Bargmann.

This work was supported in part by grants (No. 144022, 222121, and 248093) from the Ministry of Education, Science and Culture Japan.
} 


\section{MATERIALS AND METHOD}

Ten adult male newts (Cynops pyrrhogaster) caught in early spring were decapitated. The brains were dissected out and fixed in Bouin's solution. Dehydration and embedding in paraffin were done as usual. Frontal and parasagittal serial sections of $10 \mu \mathrm{m}$ in thickness were prepared from each brain and two sections were mounted on one glass slide. After deparaffinization, sections were treated with peroxidaseantiperoxidase (PAP) according to the method of STERnBERGER et al. (1970). After immersion in anti-LH-RH solution (dilution: 1/400) for $30 \mathrm{~min}$ at $37^{\circ} \mathrm{C}$ they were treated with anti-rabbit IgG solution (dilution: 1/100) for an additional $30 \mathrm{~min}$ at $10^{\circ} \mathrm{C}$, then with PAP compound solution $(0.1 \mathrm{mg} / \mathrm{ml})$ for $30 \mathrm{~min}$ at $10^{\circ} \mathrm{C}$ and finally immersed for 20 min in $3,3^{\prime}$-diaminobenzidine substrate solution with $\mathrm{H}_{2} \mathrm{O}_{2}$. Between each of these steps they were washed with PBS. After final washing with PBS they were mounted in balsam and examined by light microscopy. The specificity of anti-LH-RH was established in a previous investigation by IBATA et al. (1978). For the control, the sections on the slide were treated with anti-LH-RH absorbed by synthetic LH-RH. No immunoreactive products were observed in any part of the control sections.

\section{RESULTS}

$\mathrm{LH}-\mathrm{RH}$ reactive materials were visible as brown granular deposits. In the neuronal perikarya with positive immunoreaction these deposits appeared as homogenously distributed fine granules throughout the cytoplasm, while their neuronal processes and terminals were detected as dark brown strings of beads or dots.

\section{Location of LH-RH cell somata}

LH-RH positive neurons apparently are small cells whose axons or dendrites were difficult to confirm. They were located in restricted parts of the telencephalon; both in the nucleus of the diagonal band of Broca (DBB) and the medial septal nu-

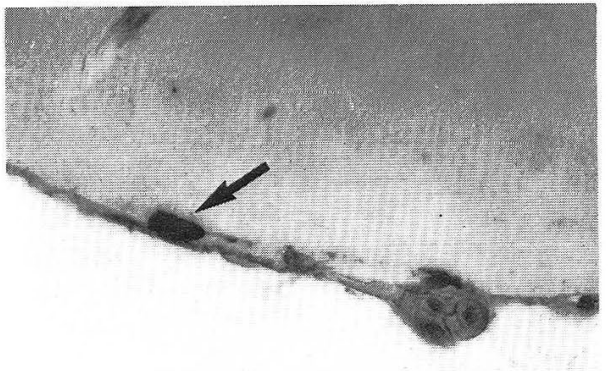

a

Fig. 1. LH-RH immunoreactive neuronal perikarya are shown in the DBB (a) and in the MSN (b). A neuron is shown located medio-laterally at the bottom of the brain (arrow) and two neurons can be seen in a dorso-ventral arrangement in the MSN (arrows). $\quad \times 680$

\section{b}


cleus (MSN) (Fig. 1a, b). In the DBB they were situated along the bottom of the brain in a rostro-lateral to caudomedial direction (Fig. 4). In the MSN, on the other hand, they were disposed along the longitudinal fissure of the telencephalon in a dorso-ventral direction. They also were spread in a rostrocaudal direction over a relatively long distance (Fig. 4). They were, however, completely distant from the anterior border of the preoptic recessus, the limit of the telencephalon and diencephalon. In both nuclei they also showed continuous arrangement from the DBB to the MSN, although the ratio of the neurons with $\mathrm{LH}-\mathrm{RH}$ immunoreactivity to all the neurons contained in both nuclei was considered to be quite small.

Pathways and terminals of LH-RH neurons

The major pathways of the LH-RH neurons whose perikarya were located in the DBB and the MSN were classified into three groups from reconstruction of serial sagittal sections. The first group of fibers originating mainly from the perikarya in the MSN ran as a converging bundle of fibers towards the optic chiasma, then emanated laterally over the optic chiasma (Fig. 2a) and reconverged as vertically thin and horizontally broad bundles in which some of the fibers from both sides crossed and projected to the median eminence. Their terminals were sparse in the rostral median eminence but large numbers of immunoreactive deposits were found in the central median eminence especially in the median and paramedian parts of the external layer (Fig. 2b, c). Some of them passed through the internal layer of the median eminence and terminated in the posterior pituitary. A few of the fibers diverged from the main pathway just caudal to the optic chiasma and ran

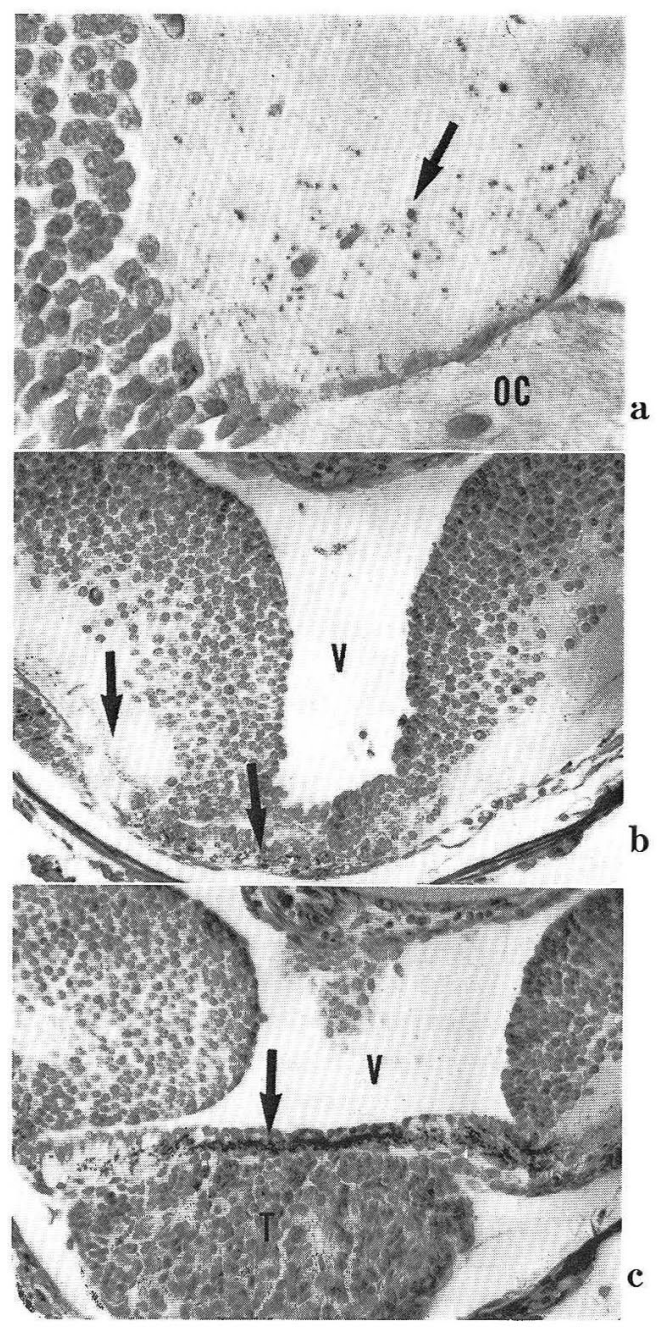

Fig. 2. a-c. LH-RH neuronal pathway projecting to the median eminence and their terminal features are shown in these figures. a. Widely distributed neuronal processes shown as dark deposits (arrow) are observed above the optic chiasma. $\times 560$. b. Sparsely distributed tiny nerve endings (arrows) are shown in the external layer of the rostral median eminence. $\times 280$. c. Large numbers of terminals particularly in the median and paramedian parts (arrow) are distributed in the external layer of the central median emincncc. $\times 280$. OC optic chiasma, $V$ third ventricle, $T$ tuberal lobe of the anterior pituitary. 
a
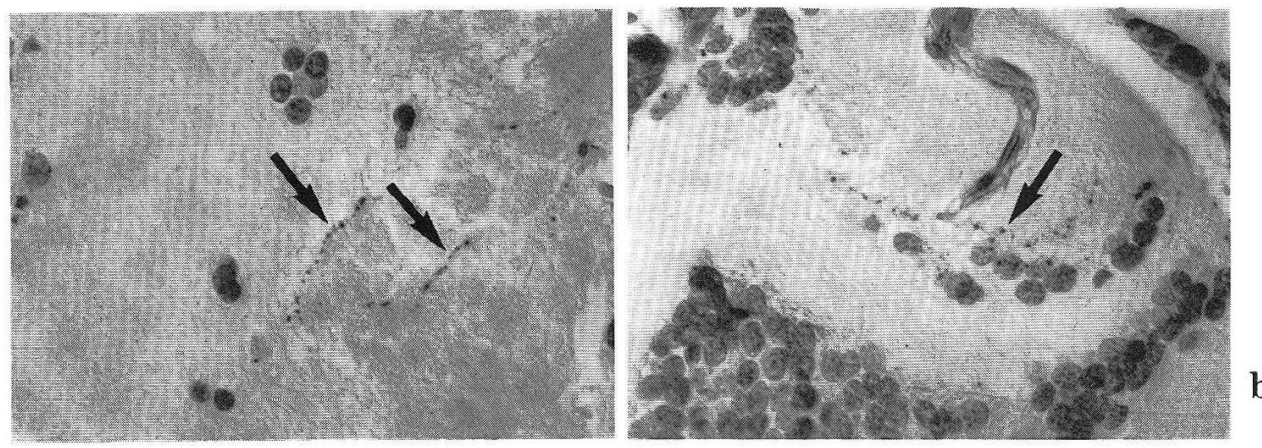

Fig. 3. Extrahypothalamic LH-RH terminals are shown in the glomerulus of the olfactory bulb (a) and in the habenular nucleus (b). Dark strings of beads (arrows) are seen in both areas and they are distributed around the neurons in the havenular nucleus (arrow). $\times 560$

along the floor of the third ventricle towards the midbrain: the ventral tegmental area in mammals. However, it was difficult to trace these fibers to the terminal portions.

The second group of fibers arising mainly from LH-RH immunoreactive neurons in the DBB ran rostro-laterally at the bottom of the brain and then turned in a rostrodorsal direction through the lateral margin of the telencephalon and entered the olfactory bulb. Their nerve endings were conspicuously detected as tiny brown varicosities or dots in the olfactory glomerulus (Fig. 3a).

The third group of fibers arising mainly from LH-RH immunoreactive neurons in the MSN ran dorso-caudally above the thalamus in the median line and entered the habenular nucleus. The nerve terminals which appeared as brown dots were abundant in the caudal part of this nucleus (Fig. 3b). Some of these fibers were considered to project further to the epiphysis through the habenular commissure. The location, pathways and terminals of LH-RH neurons were schematically summarized in Figure 4.

\section{DISCUSSION}

The present study demonstrated that in the newt, neurons immunoreactive to antiLH-RH were situated in restricted areas of the DBB and MSN. The previous studies in some species of the frog brain demonstrated a relatively wide distribution of LH-RH neurons throughout the telencephalon and diencephalon (DoERR-SchotT and Dubois, 1976; AlperT et al., 1976; Goos et al., 1976). In the Rana esculenta, LH$\mathrm{RH}$ neurons are localized in the region in front of the preoptic recess (Goos et al., 1976), in the Xenopus laevis they are distributed in a broad area from the telencephalon to the diencephalon (Doerr-Schotт and Dubois, 1976). Only in the Rana pipiens are they localized in the medial septal nucleus where LH-RH neurons were demonstrated in the newt in the present investigation. Therefore, LH-RH neurons in the newt are considered to be located more rostrally and in a narrower region than in the frog. Whether this difference with respect to their location is due to 

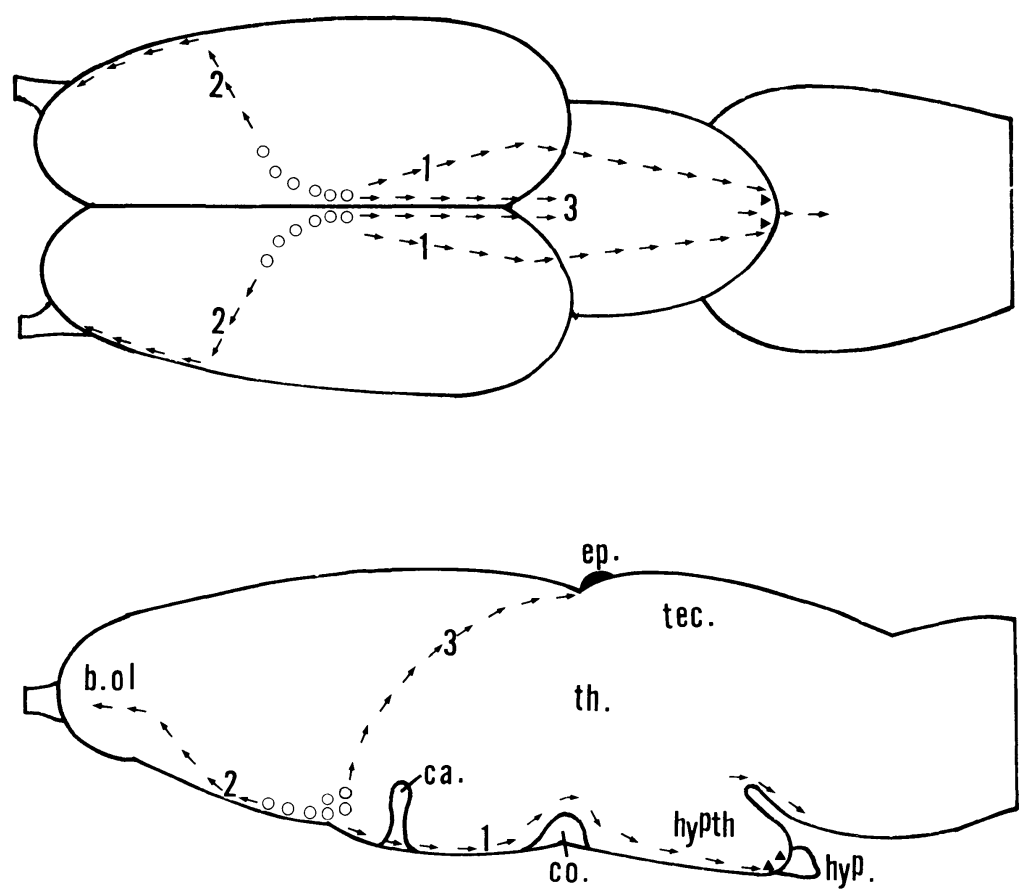

Fig. 4. A diagram showing the distribution and pathways of the LH-RH neurons in horizontal and parasagittal views. The location of the LH-RH neurons in both the DBB and the MSN is represented by circles. Three pathways are indicated as 1 : projection to the median eminence, 2 : to the olfactory bulb, 3: to the habenular nucleus. $\quad b . o l$ Olfactory bulb, $c a$ anterior commissure, co optic commissure, hypth hypothalamus, hyp hypophysis, $e p$ epiphysis, th thalamus, tec tectum.

species difference, in brain construction, or to the anti-sera employed is unclear, since even in mammals conflicting conclusions have been drawn by different authors concerning the location of the perikarya of LH-RH neurons (BARRY et al., 1973; Zimmerman et al., 1974; Naik, 1975; Barry and Carette, 1975; Silverman, 1976; SÉTÁló et al., 1976). Some authors mention their location in the preoptic area or in the suprachiasmatic nucleus, others in the arcuate nucleus. Some investigators insist that the LH-RH neurons are located in both the preoptic area and in the arcuate nucleus, but that their neuronal projections are different from each other (KREY and Silverman, 1978; Silverman and Krey, 1978).

The centers involved in the control of the gonadotropic function in the amphibian have still not been clarified, although the regions such as magnocellular preoptic nucleus, the pars ventralis of the tuber cinereum and the ventral infundibular nucleus are cited possibilities (Dierickx and Vandesande 1965; Dierickx, 1974; Van OORDT et al., 1974). These regions generally correspond to the medio-basal hypothalamic area of mammals. However in the present study we could not detect LH$\mathrm{RH}$ cell somata projecting to the median eminence in this area.

The projection of the LH-RH neuron system in the newt was divided into three 
parts, although in the frog brain only one projection to the median eminence has been proved. The extrahypothalamic projection of the LH-RH neurons other than the projections to the median eminence has been demonstrated even in mammalian species (Barry and Carette, 1975; Bugnon, Bloch and Fellman, 1977; Barry, 1978; Silverman and KreY, 1978).

One of the extrahypothalamic projection of the newt in the present study seems to be quite similar to that in mammals where LH-RH neurons in the septal area project to the habenular nucleus (BARRy, 1978; Silverman and KrEy, 1978). Another extrahypothalamic projection to the olfactory bulb has not been clarified in mammals. The role of the extrahypothalamic projection of $\mathrm{LH}-\mathrm{RH}$ neurons is uncertain. $\mathrm{LH}-$ $\mathrm{RH}$ in such nerve endings in the extrahypothalamic area may act as a neurotransmitter or neuromodulator rather than as the neural hormone. We wonder why the extrahypothalamic projection of $\mathrm{LH}-\mathrm{RH}$ neurons has not been found in the frog brain which is evolutionally a more advanced form than that of the newt.

The pathway of LH-RH neurons projecting to the median eminence in the newt corresponds to that in the frog and in mammals (Doerr-Schotт and Dubois, 1976; Alpert et al., 1976; Goos et al., 1976; SÉtáló et al., 1976; IbAta et al., 1979b). However, their terminal distribution in the median eminence seems to be considerably different from that in mammals. In the newt the most remarkable and predominant distribution is seen in the median and paramedian parts of the external layer of the central median eminence, while in mammals the lateral part of the external layer of the central median eminence contains the largest amount of LH-RH immunoreactive deposits (e.g. KInG et al., 1974; Gross, 1976; IbAta et al., 1978, 1979a, b).

\section{免疫組織化学法によるイモリの LH-RH ニューロンシステムについて}

久保清一, 渡辺憲二, 井端泰彦, 佐野豊

アカハライモリの LH-RH ニューロンの細胞体の局在, 投射経路および 終末分布が 酵素 抗体法により免疫組織化学的に検索された. LH-RH ニューロンの細胞体はBroca の対角 帯核 (DBB) および内側中隔核 (MSN) に局在して認められ，前者においては細胞体は脳 底に沿って吻外側から尾内側方に分布が見られ，後者においては 背側から腹側へ配列す る細胞体が吻側から尾側方向へ数列認められた。 またとれらの L 始とする投射線維は 3 群に分けられた。第 1 は正中隆起へ投射を見るもので, 主として MSN のニューロンから起こり，はじめは視交义に向かう集束した線維群として認められ， その後 視交叉上方で拡散し, 正中隆起直前で再び集束し, 正中隆起に投射する. 正中隆起 において最も密な終末分布を示す部域は，中部正中隆起外層の正中および傍正中部である. 第 2 はBB のニューロンから起始する線維群で, 脳底を吻外側に走り, その後 吻背側 方に転じ, 終脳辺縁部を吻側に進み, 嗅球に投射するものであり, この線維群は嗅球系 球体内に点状終末として認められる. 第 3 は主としてMSNのニューロンから起こり, 視 床の背側正中部を尾側方に走り, 手綱核に投射するもので, 手綱核の神経細胞周辺に 点 状終末として認められる。 またこの線維群の一部は松果体へも投射すると思われる。な 
おカエルや哺乳類における $\mathrm{LH}-\mathrm{RH}=ュ$ カンの局在や投射経路が，イモリの今回の所 見と比較検討され，若干の考察が加えられた。

\section{REFERENCES}

Alpert, L. C., J. R. Brawer, I. M. D. Jackson and S. Reichlin: Localization of LH-RH in neurons in frog brain (Rana pipiens and Rana catesbeiana). Endocrinology 98: 910-921 (1976).

Barry, J. : Septo-epithalamus-habenular LRF-reactive neurons in monkeys. Brain Res. 151: 183187 (1978).

Barry, J. and B. Carette: Immunofluorescence study of LRF neurons in primates. Cell Tiss. Res. 164: 163-178 (1975).

Barry, J., M. P. Dubois and P. Poulain : LRF producing cells of the mammalian hypothalamus. A fluorescent antibody study. Z. Zellforsch. 146: 351-366 (1973).

Bugnon, C., B. Bloch and D. Fellman: Étude immuno-cytologique des neurones hypothalamiques á LH-RH chez le foetus human. Brain Res. 128: 249-262 (1977).

Dierickx, K.: Identification of adenohypophysiotropic neurohormone producing cells in Rana temporaria. In: (ed. by) S. F. Knowles and L. Vollrath: Neurosecretion-The final neuroendocrine pathway. Springer, Berlin-Heiderberg-New York, 1974. (p. 178-181).

Dierickx, K. and F. Vandesande: The magnocellular preoptic nuclei and the reproduction in Rana temporaria. Z. Zellforsch. 68: 190-193 (1965).

Doerr-Schott, J. and M. P. Dubois : LHRH-like system in the brain of Xenopus laevis Daud. Cell Tiss. Res. 172: 477-486 (1976).

Goos, H. J. Th., P. J. M. Ligtenberg and P. G. W. J. van Ooradt : Immunofluorescence studies on gonadotropin releasing hormone (GRH) in the fore-brain and neurohypophysis of the green frog, Rana esculenta L. Cell Tiss. Res. 168: 325-333 (1976).

Gross, D. S. : Distribution of gonadotropin-releasing hormone in the mouse brain as revealed by immunohistochemistry. Endocrinology 98: 1408-1417 (1976).

Ibata, Y. and K. Watanabe: A morphological survey of the median eminence: Fluorescence histochemistry, electron microscopy and immunohistochemistry. Arch. histol. jap. 40, Suppl.: 303-315 (1977).

Ibata, Y., K. Watanabe, H. Kimura, Y. Sano, S. Sin, E. Hashimura and K. Imagawa : Distribution of LH-RH nerve endings in the median eminence of proestrus female rats: Fluorescence and peroxidase anti-peroxidase (PAP) immunohistochemistry. Endocrinol. jap. 25: 141148 (1978).

Ibata, Y., K. Watanabe, H. Kinoshita, S. Kubo, Y. Sano, S. Sin, E. Hashimura and K. Imagawa: Detection of catecholamine and luteinizing hormone-releasing hormone containing nerve endings in the median eminence and the organon vasculosum laminae terminalis by fluorescence histochemistry and immunohistochemistry on the same microscopic sections. Neurosci. Letters 11: 181-186 (1979a).

Ibata, Y., K. Watanabe, H. Kinoshita, S. Kubo, Y. Sano, S. Sin, E. Hashimura and K. Imagawa: The location of LH-RH neurons in the rat hypothalamus and their pathways to the median eminence. Experimental immunohistochemistry and radioimmunoassay. Cell Tiss. Res. 198: 381-395 (1979b).

King, J. C., J. A. Parson, S. L. Erlandsen and T. H. Williams : Luteinizing hormone-releasing hormone (LH-RH) pathways of the rat hypothalamus revealed by the unlabeled antibody peroxidase-antiperoxidase method. Cell Tiss. Res. 153: 211-217 (1974).

Krey, L. C. and A. J. Silverman : The luteinizing hormone-releasing hormone (LH-RH) neuronal networks of the guinea pig brain. II. The regulation on gonadotropin secretion and the origin 
of terminals in the median eminence. Brain Res. 157: 247-255 (1978).

McNeill, T. H., G. P. Kozlowski, J. H. Abel, Jr. and E. R. Zimmerman: Neurosecretory pathways in the mallard duck (Anas platyrhynchos) brain: Localization by aldehyde fuchsin and immunoperoxidase techniques for neurophysin (NP) and gonadotrophin releasing hormone (Gn-RH). Endocrinology 90: 1323-1332 (1976).

Naik, D. V.: Immunoreactive LH-RH neurons in the hypothalamus identified by light and fluorescent microscopy. Cell Tiss. Res. 157: 423-436 (1975).

Oordt, P. G. W. J. van, H. J. Th. Goos, J. Peute and M. Terlou: Structural and functional aspects of two types of Gomori-negative neurosecretory centres in the caudal hypothalamus of Amphibia. In: (ed. by) F. Knowles and L. Vollrath: Neuresecretion-The final neuroendocrine pathway. Springer, Berlin-Heiderberg-New York, 1974. (p. 182-192).

Sétáló, G., S. Vigh, A. V. Schally, A. Arimura and B. Flerkó: Immunohistological study of the origin of LH-RH containing nerve fibers of the rat hypothalamus. Brain Res. 103: 597602 (1976).

Sharp. P. J., E. Haase and H. M. Fraser : Immunofluorescent localization of sites binding antisynthetic LHRH serum in the median eminence of the greenfinch (Chloris chloris L.). Cell Tiss. Res. 162: 83-91 (1975).

Silverman, A. J. : Distribution of luteinizing hormone-releasing hormone (LH-RH) in the guinea pig brain. Endocrinology 99: 30-41 (1976).

Silverman, A. J. and L. C. Krey : The luteinizing hormone-releasing hormone (LH-RH) neuronal networks of the guinea pig brain. I. Intra- and extrahypothalamic projections. Brain Res. 157: 233-246 (1978).

Sternberger, L. A., P. H. Hardy, Jr., J. J. Cuculis and H. G. Meyer: The unlabeled antibody enzyme method of immunohistochemistry. Preparation and properties of soluble antigenantibody complex (horseradish peroxidase-antihorseradish peroxidase) and its use in identification of spirochetes. J. Histochem. Cytochem. 18: 315-333 (1970).

Zimmerman, E. A, K. C. Hsu, M. Ferin and G. P. Kozlowski : Localization of gonadotropinreleasing hormone (Gn-RH) in the hypothalamus of the mouse by immunoperoxidase technique. Endocrinology 95: 1-8 (1974).

井端泰彦

厂602 京都市上京区河原町通広小路 京都府立医科大学

第二解剖学教室
Dr. Yasuhiko Iв Aт A

Department of Anatomy

Kyoto Prefectural University of Medicine

Kawaramachi Hirokoji

Kyoto, 602 Japan 